\title{
REAL ESTATE DUE DILIGENCE PROCESS IN INTERNATIONAL REAL ESTATE TRANSACTIONS IN LATVIA Janis VIESTURS ${ }^{1}$, Armands AUZIN̦Š2 \\ ${ }^{1,2}$ Riga Technical University, Latvia janis.viesturs@edu.rtu.lv armands.auzins@rtu.lv
}

\begin{abstract}
International real estate transactions, especially in countries with different legal systems, are characterised by the fact that each transaction is unique in its complexity, confidentiality, different risk factors, and the limited availability of information regarding the real estate. The Due Diligence (DD) process is an instrument that can help avoid or at least reduce risks and assist in making important decisions regarding real estate transactions. The term "Due Diligence" has a number of different meanings. The aim of this paper is to determine the etymology of this term and to identify its most common contemporary meaning. Each DD process is to be recognised as a project requiring management because of the potentially high number of individuals that could be involved.
\end{abstract}

Keywords: Due diligence, due diligence framework, real estate investigation, real estate transactions, vendor due diligence.

\section{INTRODUCTION}

International real estate transactions are characterised by the fact that each transaction differs and dictates variable requirements and approaches (Guidelines for Due Diligence on Real Estate in the UK, 2013), is unique with its complexity (Seabrooke and How, 2004), confidentiality, limited availability of information regarding the real estate, as well as its interdisciplinarity (Malloy, 2005), and especially, because of the relatively high property values and transaction costs. Therefore, surprisingly, in real estate transactions the interested parties at times thoughtlessly attempt to save not only on the purchase price of the property, but also on the various costs involved in the transaction investigation process, which include notary, attorney services, etc. In Latvia, the fact that transactions are not entrusted to professionals is evidenced by the high percentage $(95 \%)$ of private agreements that are used in transactions when compared to the number of "notarial acts". According to the following sociological survey: "The proportion of shadow economics in real estate transactions, individual expertise and proficiency in civil law transaction deals and common problems", organised by the marketing and public opinion research centre "SKDS" in 2015, as much as $44 \%$ of the private agreements used in real estate transactions are drafted by the individuals themselves, not by professional lawyers (Litvins, 2015). This implies that the parties buying and selling real estate often believe that they themselves are sufficiently qualified to conduct real estate transactions without a thorough analysis of the legal process, economic, planning and construction aspects 
involved. This is the case, for example, in Poland (Jasińska, 2014) and also in Latvia.

Usually upon entering into a real estate purchase agreement, the buyer affirms that he has familiarised himself with the property, its factual condition, as well as with any rights in rem that encumber the property and has no objection to these. Both parties by the agreement affirm that they are well aware of the property value, its correspondence to the purchase price, that they understand the contents of the agreement and any consequences therein, consider the agreement as fair, that it expresses their true will, and both parties resolve not to put forth any material (or other) claims against each other regarding any inadequacies or excessive losses that may be associated with the purchased real estate. The question remains whether or not the buyer - a non-professional - has truly familiarised himself with the property that is being purchased.

Traditionally, a real estate purchase is viewed as a non-emotional act. However, a good indicator that a real estate transaction can be an emotional purchase is the option available in some countries to retract an agreement without loss or penalty in order to protect buyers, i.e. non-professionals, from spontaneous purchases. For example, in the Netherlands, the "cooling-off period" is 3 days. In France and Belgium (in French Délai de rétraction), there is a 7-day contemplative period in which the buyer can opt out of the purchase agreement without any loss or penalty. In order to avoid potential regret of purchase, it is highly recommended that the buyer thoroughly familiarise himself with the real estate object by carrying out a DD investigation.

This study consisted of researching the etymology of the term "Due Diligence" and how the term is used today. In the process of the research the experts who are traditionally most often involved in real estate transactions were identified and determination was made who among them would be most competent to manage the real estate DD process in Latvia. A group of 18 professional real estate agents from the Latvian Real Estate Association "LANIDA" was surveyed for the purpose of receiving their professional feedback and opinion about the DD process (hereafter "Survey"). A number of research methods were employed for the research, including the historical, empirical and comparative analysis of the DD process, as well as the examination of expert assessments. The current legislation of Latvia was analysed and pertinent literature was reviewed during the research.

\section{ETYMOLOGY OF THE TERM “DUE DILIGENCE”}

The term "Due Diligence" comes from latin terms diligentia - care, carefulness, and due - proper, reasonable. The term "Due diligence" began to be widely used in the United States in the 1930s when the United States Congress enacted the Securities Act of 1933 after the stock market crash in 1929. The law (Act) was adopted to protect investors against fraud and to promote ethical standards of honesty and fair dealing (Sjorstrom, 2006). According to the Securities Act, in the case of fraud in acquiring such securities, the defrauded person has a right to sue those responsible (including 
the directors, chief executive officers, chief financial officers, auditors and the underwriters) either at law or in equity in any court of competent jurisdiction (Securities Act, 1933) unless it can be proved that at the time of the acquisition the defendant knew of the untruth or omission. If the entity selling equities exercised DD, then as the defendant they can proceed with a "Due Diligence defence" if, after the reasonable investigation, they had reasonable ground to believe and did believe that the statements contained therein were true (Securities Act, 1933). Hence, entities selling equities are free from liability, if they can prove that a "reasonable investigation" or "Due Diligence" was conducted before the transaction took place.

\section{CONTEMPORARY USE OF THE TERM “DUE DILIGENCE”}

It is widely understood that the DD process is requested by the buyer (also "Acquiror Due Diligence" or "Buy Side Due Diligence") and should always precede the transaction of real estate. In cases where DD was not carried out on the basis of 'trust' or other reasons, it is recommeneded that the buyer carry out a DD after the fact, i.e. "Postcontractual Due Diligence" (Lars, 2011).

DD has a number of definitions, for example:

- A checklist, which is a systematic approach to identify all essential factors to be taken into account when acquiring real estate. This checklist generally consists of many parts, primarily: the location, building materials and building quality, interior design, installations and household technology, security, legal questions concerning the real estate and its acquisition, legal questions on structuring real estate ownership, renovations and building-law restrictions, taxes, inheritance law aspects, and others (Kälin \& Taylor, 2013);

- A method of analysis to systematically reduce the risk in real estate aquisition (Hellerforth, 2008);

- A multi-phase transparent, documented process, by which objectively, according to unified specifications, economic and technically important data, facts, influencing factors and characteristics of a real estate object are verified, analysed, and evaluated (Reis, 2005), thus creating a solid foundation for decision-making for the diligent entrepreneur (Teufelsdorfer \& Fischer, 2013);

- DD in a broader meaning means provision of information, verification, preparation, analysis and documentation regarding potential purchase of the enterprise and in the narrower meaning it means the analysis of the enterprise to increase the quality in decision-making and assurance against aquisition risks (Lars, 2011);

- A real estate investigation which usually consists of many sections to be examined - legal, technical, financial, taxation, environmental (Hellerforth, 2008) and other areas. These sections are determined by each particular transaction and practice in a country;

- In the Guidelines for Due Diligence on Real Estate in the UK created by the Commercial Real Estate Finance Council Europe, it is emphasised 
that every transaction has differences but there does remain "a core diligence process common to most", which is: "The process of factual and legal investigation, research, analysis and discovery into the relevant borrower, asset, sponsor and other principal parties typically undertaken by a prospective buyer, lender or investor prior to entering into a transaction" (Guidelines for Due Diligence on Real Estate in the UK, 2013, 4.).

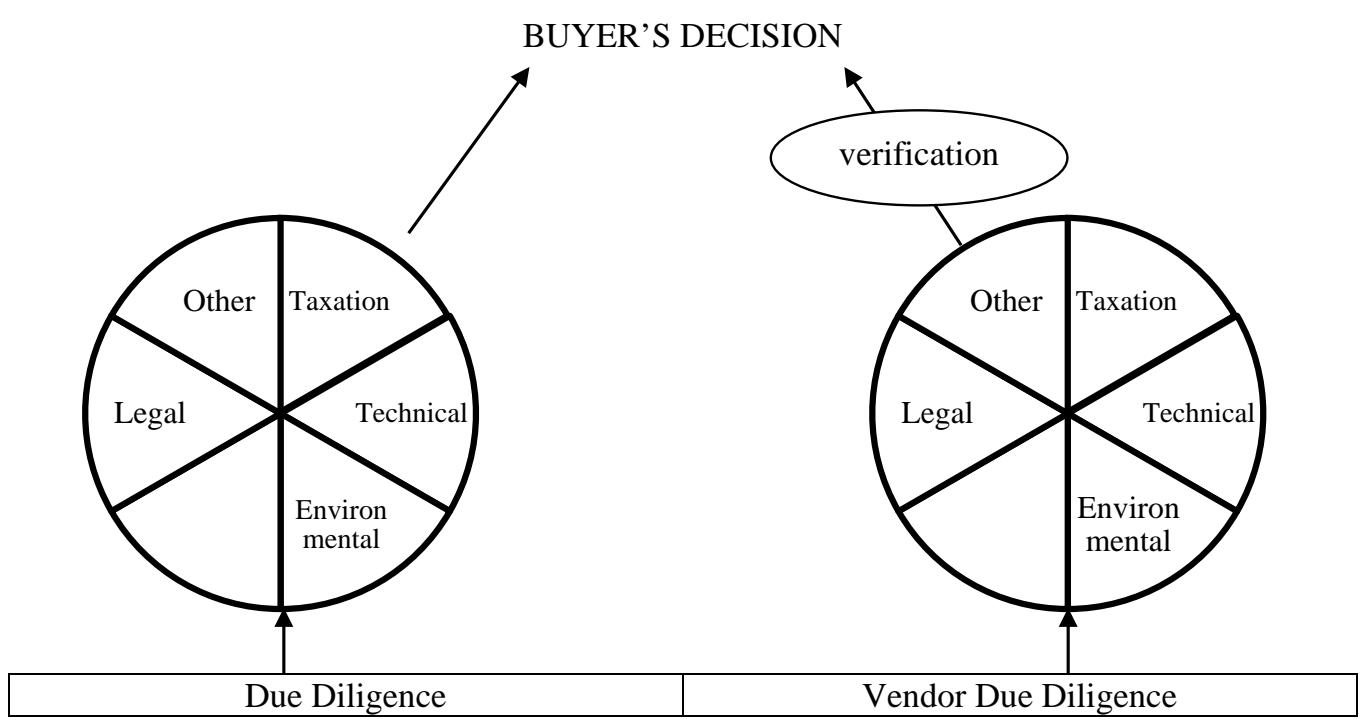

Fig. 1. Due Diligence and Vendor Due Diligence sections

(figure made by the authors).

For each DD process, it is recommended that the appropriate element parameters be defined and that the required competent experts be chosen. Apart from the buyer, the seller can also be the initiator of the DD process, which can accelerate the selling process. In this case, the DD process is then called "Vendor Due Diligence", "Reverse Due Diligence" or "Sell Side Due Diligence”, which, in practice, is used less frequently as is indicated by our Survey (see Fig. 5). Consequently, the buyer can choose to perform verification of the Vendor Due Diligence. Usually, the DD process is a "Full Scope Due Diligence"; however, it is possible to perform a "Limited Scope Due Diligence" (Lars, 2011). The DD process ought to conclude with a report containing the following sections (note: these are not regulated, thus, can differ according to each transaction and the traditions in each particular country): 1) Title; 2) Table of Contents; 3) Definitions and Abbreviations; 4) Parameters; 5) Short Summary; 6) Detailed Account of Each Section; 7) Appendices.

Empirical research shows that every country uses some type of a partial or complete DD process. Many emphasise environmental DD: "most, if not all, lenders will require some type of environmental due diligence as a condition precedent to closing on the loan" (Matter, 2010, 1), especially if the real estate is located in or near a contaminated area (Olson, Bergamini, 2004, 2005). Energy Performance Certificates in the EU can be described as part of DD process or "Limited Scope Due Diligence" according to Directive 2002/91/EC of the 
European Parliament and of the Council of 16 December 2002 on the energy performance of buildings. Certain countries require some mandatory procedures regarding the real estate investigation in the process of the transaction. For example, in the countries that use the civil law system, legal assistance of a notary is required to corroborate the property rights of real estate in the land registry. In France, in the resale of property, the seller is required to provide a number of reports on the condition of the property being sold, including reports on asbestos, lead and termites; a report on natural and technological hazards, an energy performance inspection, a gas inspection for premises with an interior gas installation, and an inspection of interior electrical systems. In the UK, Energy Performance Certificates are required. In Scotland, in case of the transaction of an apartment in an apartment building a Home Report is required, which consists of: 1) a house condition survey and valuation; 2) a property questionnaire; and 3) an energy report. Thus, DD can be a legal obligation, but it is more commonly used to describe voluntary investigations and has long been standard practice for anyone considering the purchase of a business, assets, or real estate (Connolly, Morton, 2015).

\section{DUE DILIGENCE AS A MANAGEMENT PROJECT}

In carrying out DD, it is recommended that it be regarded as an interdisciplinary management project (Wunschel, 2009) with its goal being a final DD report to help the buyer decide whether or not to aquire the property or to continue to discuss the conditions of agreement: "Skeletons found in Due Diligence should not normally break a deal but they will be negotiating points on the way, with luck, to agreement" (Howson, 2003, 3).

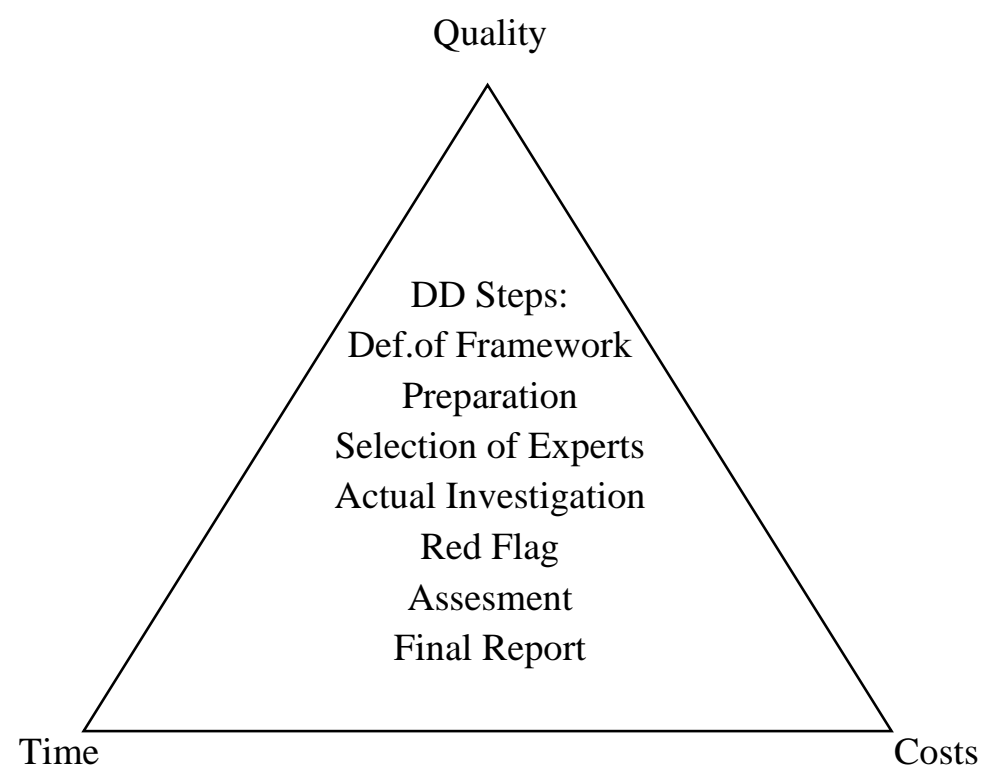

Fig. 2. Due Diligence as a management project (figure made by the authors). 
Each real estate DD is a project because it is characterised by these factors: 1) it is unique; 2) it has a specific goal; 3) it has set limits on time, finances, and resources (which can vary). In real estate DD, the management of the project is of utmost importance, understanding it to be: "The planning of tasks, resources, organization and management in order to reach the goal of the project, and to control its strategic implementation" (Tambovceva \& Tambovcevs, 2012, 16). In order for the project to be implemented as initially planned, it is necessary to determine the parameters of these three elements: time, costs and quality (see Fig. 2). Changing the parameters of one inevitably affects the other two.

The DD process consists of many steps: 1. Defining the Framework - setting the parameters and methods of analysis of the DD project according to the client's specifications. It is also necessary to determine how extensive the DD will be. It is worthwhile to note that, potentially, the buyer can become better informed about the real estate than its seller; 2. Preparation - setting up the structure and communication for the project, as well as preparing the project documents (Teufelsdorfer \& Fisher, 2013); Reis J. (2014) recommends the creation of a "virtual project office"; 3. Selection of experts and assembling of the project team. It is within the project manager's responsibility to choose the necessary experts as well as to determine which parts of the project can be done by himself; 4. Research by each expert and their interdisciplinary cooperation; 5. Red Flag determining all aspects (also called "deal breakers") which could potentially cause hindrances to the fulfilling of the real estate transaction, as well as their possible solutions. An example of a "Red Flag" would be the discovery that the buyer by law is ineligible to buy particular real estate, for example, agricultural land; 6. Compiling expert assessments; 7. Final report.

\section{THE DUE DILIGENCE PROCESS IN LATVIA}

In real estate transactions in Latvia, the term "Due Diligence" is used very rarely, with the exception being in international real estate transactions. However, this does not mean that the DD process in not being utilised. As our Survey results revealed, real estate agents are familiar with the term and $38 \%$ of the agents acknowledged having written a DD report. The DD process in Latvia is not regulated by law and there are no mandatory real estate investigation requirements to fulfil prior to a real estate transaction. A few exceptions are the legal investigation made by the notary in cases when the agreement is made as a "notarial act", as well as the minimum legal investigation a notary must do as part of preparing "Requests for corroboration" in the Land Registry. The Civil Law of the Republic of Latvia, article 1612 prescribes: "The alienator shall be liable not only for the faults and defects of the alienated property of which he or she had knowledge but did not declare, but also for hidden defects of which he or she did not have knowledge". Hence, it is in the best interests of the seller to conduct a thorough investigation of the property (through DD), thus absolving himself of any liability for the faults and defects of the alienated property.

The increased adherence to higher professional standards in international real estate transactions, as well as portfolio diversification, and the decreased 
restrictions on capital movement are some of the main factors driving increased international transactions (Just, 2007). This increasing professionalism in the international real estate arena is a global tendency which, as a consequence, increases the number of international real estate transactions and the amount of foreign direct investment (FDI) in enterprises carrying out real estate activities in Latvia (see Fig. 3).

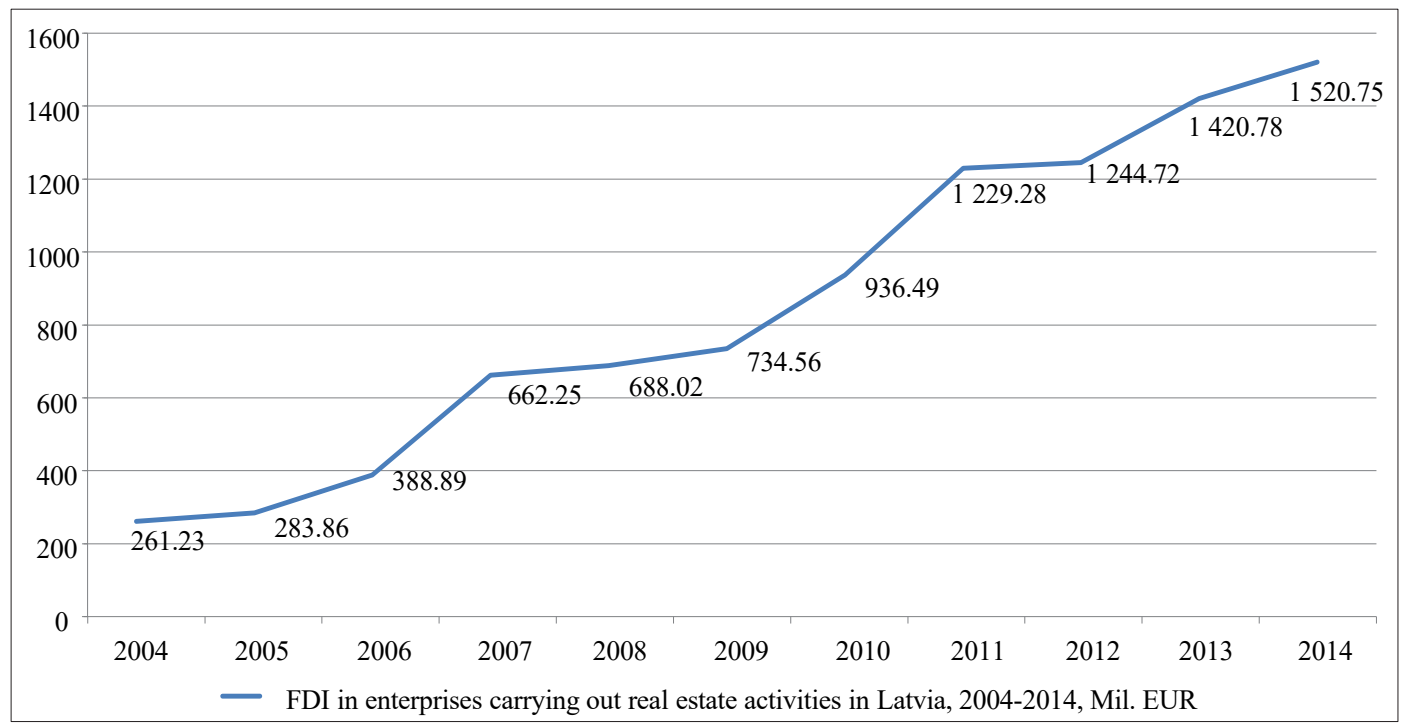

Fig. 3. FDI in enterprises carrying out real estate activities in Latvia, 2004-2014. Source: Bank of Latvia, figure made by the authors.

Performing the DD process in a professional manner is top priority. Identifying the professional experts is a key. According to the Survey - in which each participant could nominate one or more professions - the Survey respondents (real estate agents) identified the real estate agent as "most competent" to carry out DD. The full results are presented in Fig. 4.

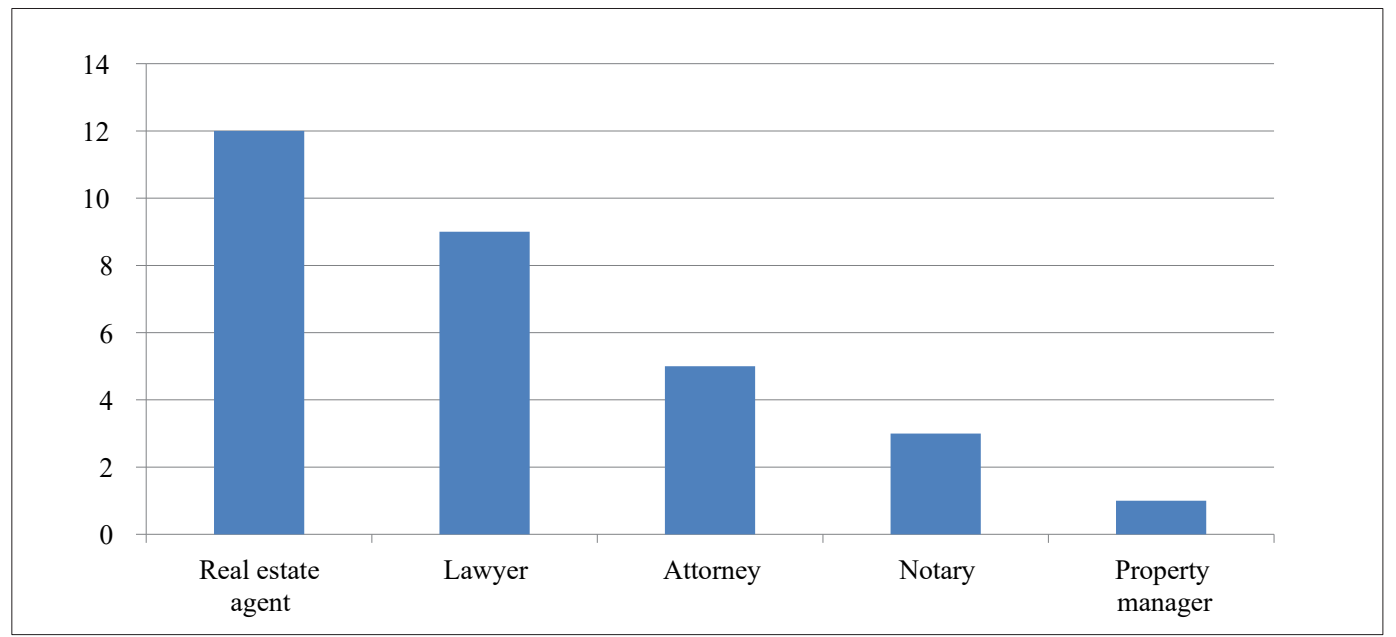

Fig. 4. Survey results: Professions most competent to carry out DD

(figure made by the authors). 


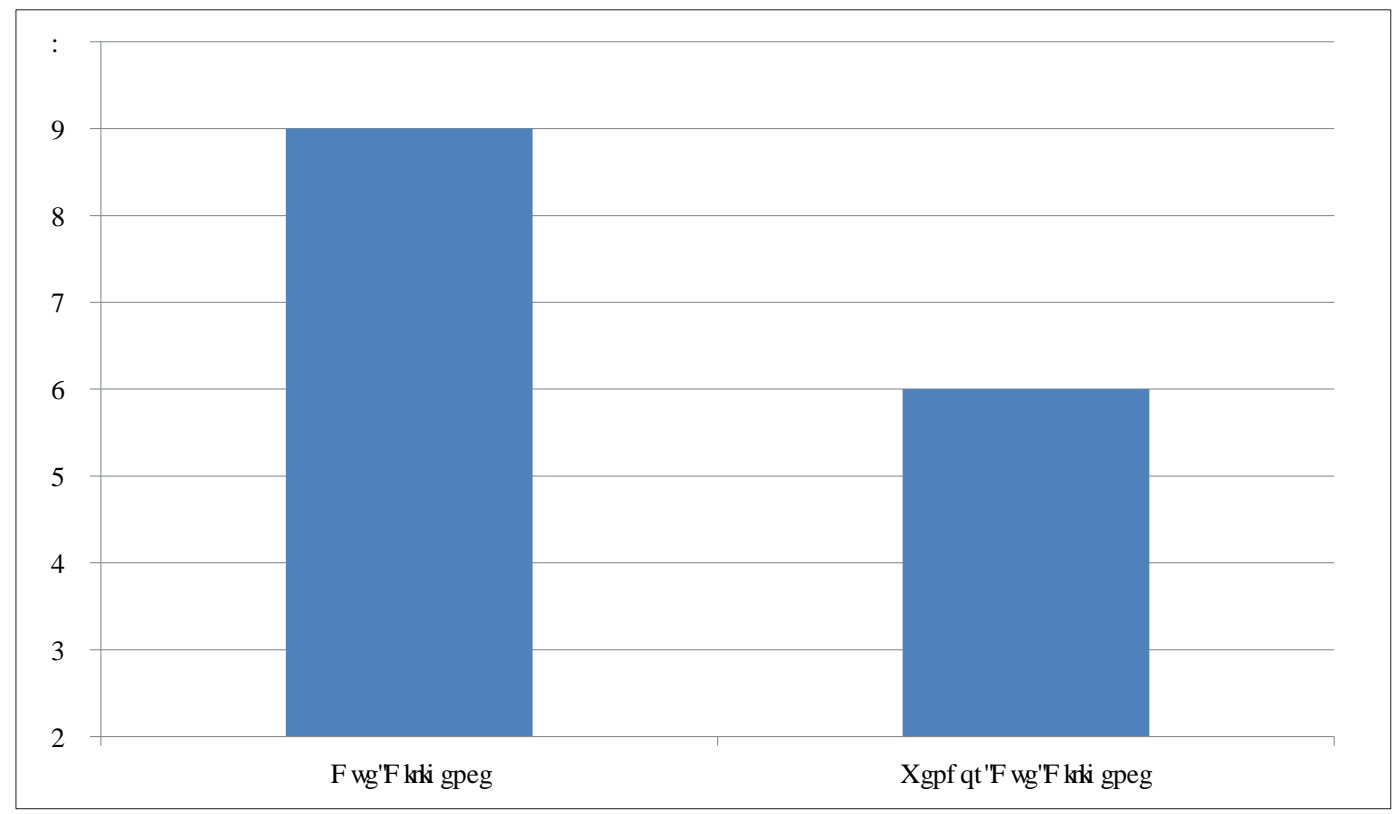

Fig. 5. Survey results: Number of real estate agents, who have performed DD or a Vendor Due Diligence in writing (figure made by the authors).

\section{PROFESSIONALS PARTICIPATING IN REAL ESTATE TRANSACTIONS}

Many professionals, regulated and non-regulated, are involved in the real estate transaction process: real estate agents, lawyers, attorneys, licensed conveyancers (for example, in the United Kingdom), notaries (in the countries of the civil law system), tax consultants, economists, facility managers, asset managers, property managers, land surveyors, appraisers of immovable property, architects, building contractors, etc. Since a "certified Due Diligence project manager" as a profession does not exist and DD can be carried out by practically anyone, the primary expert for the buyer to contact is the real estate agent, both as the channel through which to gather and gain information and as the potential expert to manage the real estate DD process.

Real estate agents, according to the International Standard Classification of Occupation (ISCO), "arrange the sale, purchase, rental and lease of real property", but their scope of operation can differ in each country. They can include: finding a buyer/seller, obtaining information, playing an extensive consultative role, providing legal assistance for the transaction, drafting the purchase agreement (for example: "Nordic type" real estate agents in Scandinavian countries (Schmid \& Hertel, 2005)), as well as carrying out the DD process.

The status of the real estate agent can be regulated or non-regulated. In social significance, the real estate agent profession represents protection for consumers and recipients of services, fraud prevention, as well as protection for creditors. In many countries, because of public policy, real estate agents are included among the regulated professions. Two such countries are the United States and Canada. 
In the European Union, in accordance with Directive 2006/123/EC of the European Parliament and of the Council of 12 December 2006 on services in the internal market real estate services such as estate agencies, the regulation/ non-regulation of this profession is entrusted to each Member State. In more than half (18) of the European countries, the real estate agent profession is considered to be regulated within the meaning of Article 3(1)(a) of Directive 2005/36/EC (Mutual evaluation of regulated professions, 2014). These countries are: Belgium, Denmark, Ireland, Spain, France, Croatia, Italy, Cyprus, Luxembourg, Hungary, Austria, Slovenia, Slovakia, Finland, Sweden, Iceland, Norway, and Switzerland. However, 14 European countries do not regulate the profession: Bulgaria, the Czech Republic, Germany, Estonia, Greece, Latvia, Lithuania, Malta, Portugal, Romania, the United Kingdom, Liechtenstein, the Netherlands and Poland. In the Netherlands, real estate agents were a regulated profession until 2001. In Poland, real estate agents were regulated from 1998 until 2013. Afterwards, from 2014 the market was opened to new professions and the real estate agent responsibilities fell on people not professionally educated in this area (Jasińska, 2014).

Usually real estate agent professional operations are defined by civil codes and special real estate agent law legislation. For example:

In Denmark - according to "The Real Property Sale Act" - the real estate agent profession is regulated and real estate transactions can be performed by: 1 . a registered real estate agent (in Danish ejendomsmoegler), 2. an attorney, 3. or a real estate agent from another EU or EEA country (with conditions).

In France - January 2, 1970, "Real Estate Agent and Manager Law" 70-9 (Loi Hoguet), July 20, 1972, Décret No. $72-678$ requires each agent to be professionally licensed - carte professionnelle; to be professionally qualified; and must carry professional liability insurance.

In Sweden 2011 (1995) "Real Estate Agent Law" ("Fastighetsmäklarlag") determines that the real estate agent must operate in the interest of both parties, even though only one side hired him. Real estate agents advise in legal matters, tax matters and draft agreements (including purchase agreements). Proper education is required. Real estate agent operations are overseen by the state agency: Fastighetsmäklarnämnd. In Sweden, it appears that up to $95 \%$ of all real estate transactions are handled by real estate agents (Murray, 2007).

In Latvia, according to the law "On the Regulated Professions and the Recognition of Professional Qualifications", real estate agents are not included in the regulated profession list. Membership in the professional organisations: Latvian Real Estate Association "LANIDDA" or the Real Estate Brokers and Agents Corporation of Latvia "NIMA" is not mandatory. The scope of the real estate agent activities in Latvia is broad and could include the DD process. The application of the European standards outlined in LVS EN 15733:2010 "Services of real estate agents - Requirements for the provision of services of real estate agents" for real estate agents and adopted in Latvia on May 13, 2010, is only a recommendation and not mandatory. As already mentioned, in the Survey $38 \%$ of the real estate agents surveyed have written a DD report and also consider themselves to be competent enough to carry out the DD process. Due to the fact that the real estate agent profession is currently unregulated, the main criteria by 
which to choose a real estate agent as a DD project manager are: professionalism, trustworthiness, and experience.

\section{CONCLUSION}

The research brought to light an effective DD framework, identified the individuals and professionals involved in the DD process, and demonstrated the DD process as a management project. The self-evaluation of the real estate agents in Latvia and the European standard (LVS EN 15733:2010) "Services of real estate agents - Requirements for the provision of services of real estate agents" illustrates that real estate agents may potentially be the experts qualified enough to manage the DD process.

The following recommendations are proposed:

- It is recommended that the term "Due Diligence" in real estate transactions be used as a synonym of "Reasonable investigation" and that DD be carried out before every international (and national) real estate transaction within the framework outlined in this paper (see Figure 2);

- It is recommened: that the DD process be regarded as an interdisciplinary management project;

- In order to elevate the status of real estate agents in Latvia or other countries, it is necessary to define the real estate agent as a regulated profession;

- The professional organisation of the DD process is the key factor to provide the necessary information so the potential buyers can make an informed decision regarding whether or not to engage in an international real estate transaction.

\section{REFERENCES}

Connolly A., Morton. (2015). Environmental Due Diligence Beyond ASTM - no All Risks are Contamination. American BAR Association. Retrieved September 27, 2015, from http://apps.americanbar.org/dch/thedl.cfm\%3Ffilename\%3D/NR350400/newsletterpubs/Enviro nmentalDD.pdf-151k

Directive 2002/91/EC of the European Parliament and of the Council of 16 December 2002 on the energy performance of buildings. Retrieved August 22, 2015, from http://eur-lex.europa.eu/ legal-content/EN/TXT/?uri=celex:32002L0091

Directive 2005/36/EC of the European Parliament and of the Council of 7 September 2005 on the recognition of professional qualifications. Retrieved August 22, 2015, from http://eurlex.europa.eu/legal-content/EN/TXT/?uri=celex:32005L0036

European standard LVS EN 15733:2010 Services of real estate agents - Requirements for the provision of services of real estate agents. Retrieved September, 15, from https://www.lvs.lv/products/index

Foreign Direct Investments in Latvia. Bank of Latvia. Retrieved September 22, 2015, from http://statdb.bank.lv/lb/Data.aspx?id=131

Guidelines for Due Diligence on Real Estate in the U.K. Commercial Real Estate Finance Council Europe (2013). Retrieved August 27, 2015, from http://www.crefc.org/uploadedFiles/ CMSA_Site_Home/Global/CMSA-Europe/Committees

Hellerforth M. (2008). Immobilieninvestitionen und - finanzierung kompakt. München: Oldenburg Wissenschaftsverlag GmbH. 130. http://dx.doi.org/10.1524/9783486847383 
Howson P. (2003). Due Diligence. The Critical Stage in Mergers and Aquisitions. Burlington: Gower Publishing Company. 1-13.

Jasińska E. (2014). Real estate Due Diligence on the example of the Polish market. Conference Paper, June 2014, 14th SGEM GeoConference on Informatics, Geoinformatics and Remote Sensing, 2. http://dx.doi.org/10.5593/sgem2014/b22/s9.053

Just T. (2007). Die Immobilie als Anlageform im internationalen Vergleich. In Internationales Immobilien Management. Handbuch für Praxis Aus- und Weiterbildung. Mayrzedt H., Geiger N., Klett E., Beyerle T. (Hrsg.). München: Verlag Franz Vahlen. 55-70.

Kälin Ch. H., Taylor A. (2013). Purchase and sale of real estate. In International Real Estate Handbook. Acquisition, Ownership, Sale, Tax, estate Planning. 4th Edition. Zurich: Ideos Publication Ltd., 2013. 21-56.

Lars R. (2011). Due Diligence-prüfung im Rahmen von Unternehmensakquisitionen. In Due Diligence als Instrument des Akquisitionscontrollings. Hamburg: Diplomatica Verlag, 2011. $21-25$.

Legislation of the Republic of Latvia (1937). Latvijas Republikas civillikums [The Civil Law of the Republic of Latvia]. Retrieved September 3, from http://likumi.lv/doc.php?id=225418

Legislation of the Republic of Latvia (2001). Par reglamentētajām profesijām un profesionālās kvalifikācijas atzišanu [On the Regulated Professions and the Recognition of Professional Qualifications]. Retrieved September, 3, from http://likumi.lv/doc.php?id=26021

Legislation of the US (1933). Securities Act of 1933. As Amended through P.H.112-106, Approved April 5, 2012. U.S. Securities and Exchange Commission. Retrieved June 9, from https://www.sec.gov/about/laws/sa33.pdf

Litvins G. (2015). Nekustamā īpašuma atsavināšanas darījuma formas riski. Jurista Vārds, 10.03.2015., 10 (862), 8-9.

Malloy R. P. (2005). Real Estate Transactions: Policy Considerations for Law, Technology and Globalization. Law \& Policy, 27(1), 81-99. http://dx.doi.org/10.1111/j.1467-9930.2004.00192.x

Matter, Lisa (2010). Property Due Diligence in Today's Real Estate Market. Retail Law Strategist. Mar. 2010, 10(1), p1-5. 5p., Database: Business Source Complete. Retrieved September 17, from http://eds.b.ebscohost.com.resursi.rtu.lv/eds/pdfviewer/pdfviewer?vid=11\&sid=802b866b920a-47a3-b618-1d166301c260\%40sessionmgr120\&hid=111

Murray P. L. (2007). Real Estate Conveyancing in 5 European Union Member States: A Comparative Study. Visiting Professor of Law from Practice, Harvard Law School, Cambridge, MA, USA. Retrieved September 2, from http://www.dnotv.de/_files/Aktuelles/ murrayreportfinal310807en.pdf

Mutual evaluation of regulated professions. Overview of the regulatory framework in the real estate sector. Report based on information transmitted by Member States and on the meeting of 6 June 2014. Retrieved September 4, from http://ec.europa.eu/internal_market/qualifications/ docs/mutual-evaluation/150119-real-estate-report-final en.pdf

Olson, H. G., Bergamini T. (2004, 2005). Advance Due-Diligence Activitie Benefit Contaminated Real Estate Transactions. Real Estate Issues. Winter2003/2004, 28(4), 12-17. 6p. 1 Chart., Database: MasterFILE Premier. Retrieved September 27, from http://eds.a.ebscohost.com/eds/ pdfviewer/pdfviewer?vid=21\&sid=796afc67-a8d2-4895-a2cc-24e5babcalb1\%40sessionmgr 4001\&hid $=4202$

Preuß N., Schöne L. B. (2010). Due Diligence. In Real Estate and Facility Management. Aus Sicht der Consultingpraxis.- Berlin, Heidelberg: Springer-Verlag. 253. http://dx.doi.org/10.1007/978-3-540-88999-1

Reis J. (2005). Due-Diligence-Real-Estate. Ein strukturierter Analyseprozess zur ganzheitlichen Beurteilung von Immobilien. Masterthesis. Norderstedt: GRIN Verlag GmbH. 6.

Reis J. (2014). Zur Konzeption Und Organisation Einer Due-Diligence-Real-Estate. Akademische Arbeit. Norderstedt: GRIN Verlag GmbH. 1-35.

Schmid Ch. U., Hertel Ch. (2005). Real Property Law and Procedure in the European Union. General Report. Final Version. European University Institute (EUI) Florence/European Private Law Forum Deutsches Notarinstitut (DNotI) Würzburg. Retrieved April 20, 2015, from http://www.eui.eu/Documents/DepartmentsCentres/Law/ResearchTeaching/ResearchThemes/ EuropeanPrivateLaw/RealPropertyProject/GeneralReport.pdf 
Seabrooke W., How H. (2004). International Real Estate. An Institutional Perspective. In International Real Estate. An institutional approach. Edited by Seabrooke W., Kent P., Hwee Hong How H. Oxford: Blackwell Publishing Ltd., 6-34.

http://dx.doi.org/10.1002/9780470757543

Sjorstrom W. K. Jr. (2006) The Due Diligence Defense Under Section 11 of the Securities Act of 1933. Brandeis Law Journal, 44, 549, Retrieved from http://papers.ssrn.com/sol3/papers.cfm? abstract_id $=864584 \# \#$

Tambovceva T., Tambovcevs A. (2012). MS PROJECT 2007 būvniecības un citu projektu vadībā. Rīga: Rīga: RTU Izdevniecība. 108.

Teufelsdorfer H., Fisher P. (2013). Due-Diligence-Prozess. Handbuch Immobilientransaktionen. Herausgegeben von Herwig Teufelsdorfer. Wien: Linde Verlag. 83-119.

Wunschel J. Due Diligence (2009). In Rechtshandbuch für die Immobilienpraxis. Erwerb, Entwicklung, Bestandshaltung, Vermarktung. Balensiefen G., Bönker C., Geiger N., Schaller W. München: Verlag Franz Vahlen. 329-376.

\section{AUTHORS' SHORT BIOGRAPHY}

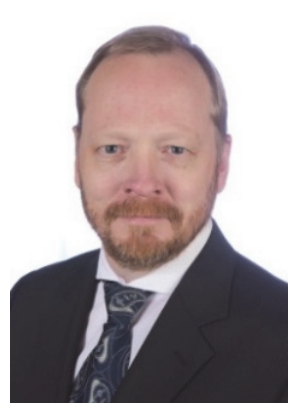

Janis Viesturs, Mg. oec., Researcher at the Faculty of Engineering Economics and Management, Riga Technical University (Latvia). Janis Viesturs has more than 20 years of experience in real estate management, development, transactions and Due Diligence process. $\mathrm{He}$ is lecturing the course "International Real Estate Transactions". Research interests: real estate definition, international and national real estate transactions, different real estate registering systems, real estate due diligence process and real estate management. He is the PhD student at RTU.

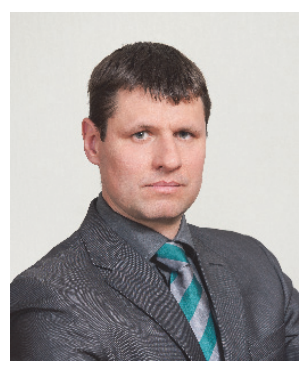

Armands Auziṇš, Associate Professor at the Faculty of Engineering Economics and Management, Riga Technical University (Latvia), Doctor of Economic Sciences, scientific expert in management and economic sciences of the Latvian Council of Science. He is a participant of the European Academy of Land Use and Development and a board member of the Latvian Association of Land Surveyors (FIG member). Associate Professor Auziňš has more than 15 years of consulting experience in land use management. His main research topic is the methodology development for evaluation of land use efficiency in land management. He is lecturing in the land management field and has published conference and journal papers, as well as participated in international research projects. His research interests include land use management, institutional and real estate economics, and evaluation techniques. 